Article

\title{
Safety Study of Sodium Pentosan Polysulfate for Adult Patients with Mucopolysaccharidosis Type II
}

\author{
Kenji Orii ${ }^{1, *, \dagger}$, Alaena Lim ${ }^{2,+}$, Shunji Tomatsu ${ }^{1,2,{ }^{\dagger}}$, Molly Stapleton $^{2}$, Yasuyuki Suzuki ${ }^{3}$, \\ Calogera M. Simonaro ${ }^{4}$, Edward H. Schuchman ${ }^{4}$, Toshiyuki Fukao ${ }^{1}$ and Tadashi Matsumoto ${ }^{5, *}$ \\ 1 Department of Pediatrics, Graduate School of Medicine, Gifu University, Gifu 501-1193, Japan; \\ stomatsu@nemours.org (S.T.); toshi-gif@umin.net (T.F.) \\ 2 Nemours/Alfred I. duPont Hospital for Children, Wilmington, DE 19803, USA; alalim@udel.edu (A.L.); \\ Molly.Stapleton@nemours.org (M.S.) \\ 3 Medical Education Development Center, Gifu University, Gifu 501-1193, Japan; ysuz@gifu-u.ac.jp \\ 4 Genetics and Genomic Sciences, Icahn School of Medicine at Mount Sinai, New York, NY 10029, USA; \\ Calogera.Simonaro@mountsinai.org (C.M.S.); edward.schuchman@mssm.edu (E.H.S.) \\ 5 ReqMed Company, Ltd., Tokyo 194-0022, Japan \\ * Correspondence: kenjior-gif@umin.ac.jp (K.O.); matsumoto@reqmed.co.jp (T.M.); \\ Tel.: +81-58-230-1111 (K.O.); +81-42-732-2207 (T.M.) \\ + These authors contributed equally to this work.
}

Received: 19 November 2019; Accepted: 9 December 2019; Published: 17 December 2019

\begin{abstract}
Current therapies for the mucopolysaccharidoses (MPS) do not effectively address skeletal and neurological manifestations. Pentosan polysulfate (PPS) is an alternative treatment strategy that has been shown to improve bone architecture, mobility, and neuroinflammation in MPS animals. The aims of this study were to a) primarily establish the safety of weekly PPS injections in attenuated MPS II, b) assess the efficacy of treatment on MPS pathology, and c) define appropriate clinical endpoints and biomarkers for future clinical trials. Subcutaneous injections were administered to three male Japanese patients for 12 weeks. Enzyme replacement therapy was continued in two of the patients while they received PPS and halted for two months in one patient before starting PPS. During treatment, one patient experienced an elevation of alanine transaminase, and another patient experienced convulsions; however, these incidences were non-cumulative and unrelated to PPS administration, respectively. Overall, the drug was well-tolerated in all patients, and no serious drug-related adverse events were noted. Generally, PPS treatment led to an increase in several parameters of shoulder range of motion and decrease of the inflammatory cytokines, MIF and TNF- $\alpha$, which are potential clinical endpoints and biomarkers, respectively. Changes in urine and serum glycosaminoglycans were inconclusive. Overall, this study demonstrates the safety of using PPS in adults with MPS II and suggests the efficacy of PPS on MPS pathology with the identification of potential clinical endpoints and biomarkers.
\end{abstract}

Keywords: PPS; anti-inflammatory factor; mucopolysaccharidosis II; glycosaminoglycan; range of motion

\section{Introduction}

The mucopolysaccharidoses (MPS) are a group of inherited metabolic disorders caused by deficiencies of the individual lysosomal enzyme(s) needed to break down glycosaminoglycans (GAGs). GAGs are long chains of carbohydrates that serve as major components of proteoglycans present in the extracellular matrix (ECM). They function to regulate the movement of molecules through the ECM and to enhance sliding between adjacent tissue; therefore, GAGs are essential to construct all connective tissues, including bones, cartilage, tendons, and skin. However, in the MPS disorders, 
GAGs accumulate in cells and connective tissues over time, giving rise to progressive damage that affects physical appearance, motor abilities, organ function, and cognitive development [1]. In total, there are 11 known enzyme deficiencies, which give rise to seven distinct MPS types that collectively affect one in every 25,000 births [2-8]. Depending on MPS type and severity, an affected individual may experience skeletal dysplasia, neurological complications, developmental delay, retinal degeneration, recurrent respiratory infection, and/or cardiac involvement [1].

MPS type II is an X-linked recessive disorder [9] caused by a deficiency of the enzyme iduronate-2sulfatase, which leads to the accumulation of the GAGs, heparan sulfate (HS) and dermatan sulfate (DS) [10]. Clinical features of MPS II include skeletal abnormalities, such as coarse facial features, joint stiffness, and short stature [11]. Like MPS I and III, MPS II also often includes significant neurological impairment. Patients with a severe form of the disorder have short life expectancy, and often, death occurs in the teenage years due to upper respiratory disease or cardiovascular failure [10].

Several therapies to address the enzyme deficiencies characteristic of MPS have been developed, mainly, enzyme replacement therapy (ERT) and hematopoietic stem cell therapy (HSCT). ERT involves injecting a functional, recombinant form of the defective enzyme(s). It has been successful in alleviating some clinical manifestations of MPS [12] and is approved for MPS I, II, IVA, VI, and VII by the Food and Drug Administration (FDA). However, ERT presents several limitations, such as high cost, need for frequent intravenous infusions, and the potential of eliciting an immune response [13-17]. More importantly, ERT provides limited or no impact on skeletal and neurological manifestations of MPS, most likely due to its limited permeability to avascular cartilage and its inability to cross the blood-brain barrier, respectively [12]. With HSCT, healthy donor cells are transplanted and serve to supply functional enzymes [18-22]. It is the main form of treatment for MPS IH, and can be used for MPS 1H/S, IS, II, IVA, VI, and VII [23-31]. However, HSCT entails several complications, such as the limited time to find a matched donor [32,33], the limited number of available donors [34,35], and risk of immune reaction (infection, organ failure graft rejection, and graft-versus-host disease) $[26,30,36]$. Furthermore, as with ERT, HSCT does not correct some MPS bone manifestations completely [22,32,37-40]. Therefore, it is important to establish alternative therapies for MPS that are non-immunogenic and can target the brain and bone.

Substrate reduction therapy (SRT) is an alternative approach to treating MPS, and several SRT agents are currently being assessed for therapeutic potential. These include genistein, rhodamine B, and Odiparcil ${ }^{\circledR}$. Instead of addressing the defective enzyme, SRT aims to reduce the biosynthesis of the substrate, in this case, GAGs. Unlike ERT, SRT is theoretically non-immunogenic [12]. Additionally, SRT with small molecules (i.e. genistein)has demonstrated the ability to cross the blood-brain barrier [41,42].

Pentosan polysulfate (PPS) is a semisynthetic, heparin-like glucosaminoglycan of low molecular weight derived from beech trees that has anti-inflammatory and pro-chondrogenic properties. PPS is FDA-approved to treat interstitial cystitis. The mechanism by which treatment occurs in this disorder is not fully established, but PPS is largely thought to replace GAGs at sites of damage in the inner wall of the bladder [43]. PPS can also block histamine release, either by inhibiting the action of mediators that recruit mast cells or by directly inhibiting mast cells themselves [44,45]. Furthermore, PPS is used off-label to treat osteoarthritis because of its pro-chondrogenic properties. PPS also stimulates hyaluronan synthesis by synovial fibroblasts and proteoglycan synthesis by chondrocytes $[46,47]$.

PPS is appealing as an agent to treat MPS since it has positive and extensive human safety data [12]. It also has broad and potent anti-inflammatory properties, and it is well documented that inflammation is an important pathogenic mediator in MPS and other lysosomal storage disorders; it even progresses in patients undergoing ERT [48]. GAG accumulation leads to activation of the toll-like receptor 4 (TLR4) pathway and subsequent release of the inflammatory cytokines, such as tumor necrosis factor- $\alpha$ (TNF- $\alpha$ ) and interleukin-1 $\beta$ (IL-1 $\beta$ ), which has major pathological effects on the joints and bones [49-51].

Based on these observations, PPS treatment led to a lowering of the inflammatory cytokines, TNF- $\alpha$, interleukin-8 (IL-8), and macrophage inflammatory protein-1 $\alpha$ (MIP- $1 \alpha)$ in several MPS animal 
models [52-54], as well as IL-1 $\beta$, TNF- $\alpha$, and interleukin-6 (IL-6) in in vitro models of Gaucher Disease and Fabry Disease [55]. Treatment with PPS also led to a significant reduction of GAG levels and alleviated MPS pathology in MPS I dogs [54], MPS VI rats [52,53], and MPS IIIA mice [56]. Currently, the mechanism of how PPS leads to GAG reduction in MPS is unknown, but this was observed in multiple animal model studies and in multiple tissues. Furthermore, Hennermann et al. demonstrated the safety of PPS in four adult MPS I patients and showed a reduction in urinary GAGs and some clinical improvements over a six month study period [57]. Each of these patients had received ERT for over one year prior to PPS and was maintained on ERT during the six-month study.

The primary goal of this study was to evaluate the safety of weekly injections in a small cohort of adult Japanese patients with MPS II. This study also aimed to assess the efficacy of PPS treatment on MPS pathology, specifically through the measurement of joint mobility, GAG accumulation, and levels of inflammatory cytokines.

\section{Materials and Methods}

\subsection{Subjects}

Informed consent was obtained for all individuals. The study was approved on (5 August 2014) by the ethics committee on human research at Gifu University (IRB number; 2652-) and followed the ethical principles of the Declaration of Helsinki. Three adult males with attenuated MPS II at 22, 34 , and 37 years of age, who will be referred to as Patients 1, 2, and 3 respectively, received weekly injections of PPS for 12 weeks at an initial dosage of $0.5 \mathrm{mg} / \mathrm{kg}$ and all subsequent injections at a dosage of $1.0 \mathrm{mg} / \mathrm{kg}$. During the trial, Patients 1 and 2 continued ERT, and for Patient 3, ERT was stopped for two months before the PPS trial. For Patients 2 and 3, injections were administered for 12 consecutive weeks; however, due to an unrelated convulsion experienced by Patient 1 after injection 6, PPS treatment was halted for two weeks and then resumed. Several assessments were performed before, during, and after the clinical trial to assess PPS injections for safety and efficacy. More details about the demographics of each patient are depicted in Table A1 in the Appendix A.

\subsection{Pathophysiological Tests}

Blood tests were performed at the start of the clinical trial and continued weekly for 14 weeks (Week 0 to Week 14). Measurements were taken for white blood cell (WBC) count, hemoglobin, platelet count, aspartate aminotransferase (AST), alanine transaminase (ALT), prothrombin time, and activated partial thromboplastin time (APTT). Although the duration of the trial was only 3 months, the following tests were conducted before and after the clinical trial in order to assess if PPS alleviated skeletal symptoms: rating of knee joint pain as reported by the patient on a $100 \mathrm{~mm}$ visual analog scale of $0-10$ (0 representing "no pain" and 10 representing "the most severe pain imaginable"), 6-min walk test (6MWT), 3-min stair climb test (3MSCT), knee joint cartilage ultrasonography, and shoulder range of motion (ROM) (flexion, extension, adduction, abduction, outer rotation, and inner rotation). Additionally, an electrocardiogram, echocardiogram, ultrasonic cardiography (UCG), brain magnetic resonance imaging (MRI), abdominal computer tomography $(\mathrm{CT})$, auditory brainstem response (ABR) test, pulmonary function test, and visual test were conducted. In general, any adverse digestive, respiratory, cardiovascular, and neurologic symptoms were recorded if detected during the trial.

\subsection{Assessment of Serum and Urine Glycosaminoglycan (GAG) Levels}

Weekly urine and blood serum samples were collected from the start of the clinical trial, before the first injection, to four weeks after the last injection. The urine samples were collected at the same time of day. These blood and urine samples were then analyzed for keratan sulfate (KS), HS, and DS using the liquid chromatography-tandem mass spectrometry (LC-MS/MS) method, as developed by Oguma and Tomatsu in 2007 [58-63]. Keratanase II, heparitinase, and chondroitinase B were added to the samples to hydrolyze KS, HS, and DS respectively, into disaccharides. The samples were then purified 
and analyzed using LC-MS/MS (1290 Infinity Liquid Chromatography with 6460 Triple Quad Mass Spectrometer by Agilent Technologies, Palo Alto, CA) to detect the disaccharides of the individual GAG polymers: monosulfated KS and disulfated KS for KS, DiHS-0S and DiHS-NS for HS, and Di-4S for DS. The concentration of each type of GAG at each time point was compared to the value in untreated subjects without MPS II obtained in the previous study [64].

\subsection{ELISA for Serum Cytokine Levels}

The following serum cytokines were measured before, during, and after the trial via enzyme-linked immunosorbent assay (ELISA): macrophage migration inhibitory factor (MIF), TNF- $\alpha$, vascular endothelial growth factor (VEGF), IL-1 $\beta$, IL-8, interleukins 10 and 18 (IL-10, IL-18), monocyte chemotactic protein-1 (MCP-1), and tumor necrosis factor receptor 1 (TNFR1). Measurements were taken at weeks $0,4,10,14$, and 17 for Patient 1 and at weeks $0,4,8,12$, and 16 for Patients 2 and 3 . All measurements were performed in triplicates according to standard protocols using human antibody ELISA kits (R and D Systems, Minneapolis, MN, USA).

\section{Results}

\subsection{Safety and Adverse Effects}

Overall, PPS was well tolerated in the patients, and no serious drug-related adverse events were noted. Patient 1 experienced a convulsion between the sixth and seventh injections. Follow-up electroencephalography (EEG) was conducted and showed mild abnormality with paroxysmal discharge, indicating that the convulsion was likely due to epilepsy. This was the second convulsion that Patient 1 experienced in his life, the first of which occurred approximately five months before the clinical trial began. Thus, it was concluded that the convulsion was not PPS-related. Additionally, Patient 3 experienced a mild elevation of ALT from weeks 6 to 11. At week 6, ALT levels were detected slightly above the normal range (5 IU/L above a range of 5 to $40 \mathrm{IU} / \mathrm{L}$ ); however, the levels decreased over time and were close to baseline by week 13 .

No other adverse effects were detected, except for mild pain and subcutaneous hemorrhage that came with injection. Such effects were temporary and disappeared within two to three days and one to two weeks, respectively. No vomiting, diarrhea, coughing, difficulty of breathing, tachycardia, or chest pain was detected within the duration of the experiment. There were no changes in electrocardiograms for any of the patients. Left atrial to aortic root ratio decreased slightly for Patient 1 and ejection fraction decreased slightly for Patients 1 and 2. According to pulmonary function test results, the overall severity of pulmonary impairment did not change with treatment. Additionally, there were no changes in hearing and visual tests, brain MRI, or abdominal CT scan with treatment. All three patients had retinitis pigmentosa and did not have hepatosplenomegaly before and after the trial. Further details of the tests assessed for adverse effects are depicted in the Appendix A, Table A2.

\subsection{Skeletal Pathophysiology}

Although the main objective of this study was to assess the safety of PPS injections in adult MPS II patients over three months, some clinical/pathological parameters were monitored for changes. Patient 1 experienced knee pain and irregularity of knee joint cartilage (as evidenced by ultrasonography) before the initiation of PPS treatment. After the three-month trial, the pain rating decreased slightly from 3 to 1 (on a scale of 10), and cartilage irregularity decreased slightly, as indicated by ultrasound examination. Patients 2 and 3 did not experience any knee pain or cartilage irregularity before the trial, and this did not change with PPS treatment.

Additionally, right and left shoulder flexion increased for Patients 1 and 2, and there was no change for Patient 3. Right and left shoulder extension decreased for Patient 2, and there was no change for Patients 1 and 3. For shoulder abduction, there was an increase observed for the right shoulder of Patient 1 and for both shoulders of Patient 2. There was also an increase in adduction 
for both shoulders for Patients 1 and 2. The degree of outer rotation decreased for both shoulders in Patient 1 and increased in the left shoulder for Patient 2. The degree of inner rotation increased for the left shoulder of Patient 1 and both shoulders for Patient 2. There was no improvement in ROM for any of these parameters in Patient 3, who was not under ERT during PPS administration. For the 6MWT and 3MSCT, there was a slight decrease in scores for Patients 1 and 2. Measurements could not be obtained for Patient 3 (not applicable, N/A). Measures of these parameters are depicted in Table 1.

Table 1. Clinical Outcomes in Mucopolysaccharidoses II (MPS II) Patients before and after Pentosan Polysulfate (PPS) Treatment.

\begin{tabular}{ccccccc}
\hline & \multicolumn{2}{c}{ Patient 1 } & \multicolumn{2}{c}{ Patient 2 } & \multicolumn{2}{c}{ Patient 3 } \\
\cline { 2 - 6 } & Before & After & Before & After & Before & After \\
\hline 6-Minute Walk Test & $495 \mathrm{~m}$ & $480 \mathrm{~m}$ & $425 \mathrm{~m}$ & $410 \mathrm{~m}$ & N/A & N/A \\
3-Minute Stair Climb Test & 173 steps & 153 steps & 188 steps & 187 steps & N/A & N/A \\
Shoulder Range of Motion & & & & & & \\
Flexion & R 134, L130 & R 140, L 140 & R 126, L124 & R 132, L138 & R 170, L170 & R 170, L170 \\
Extension & R 50, L 45 & R 50, L 45 & R 50, L 45 & R 48, L 43 & R 30, L 30 & R 30, L 30 \\
Abduction & R 90, L 130 & R 120, L 130 & R 80, L 80 & R 128, L 148 & N/A & N/A \\
Adduction & R 28, L 38 & R 60, L 55 & R 20, L 20 & R 52, L 37 & N/A & N/A \\
Outer rotation & R 70, L 90 & R 65, L 80 & R 5, L 5 & R 5, L 6 & N/A & N/A \\
Inner rotation & R 90, L 51 & R 90, L 90 & R 10, L 10 & R 85, L 80 & N/A & N/A \\
\hline
\end{tabular}

\subsection{Urinary GAG Levels}

Overall, large ranges of values were observed for urinary GAGs. No clear trends were observed in all three patients. Additionally, it could not be concluded what kind of change, if any, was induced by PPS treatment, as urinary GAG levels underwent dramatic fluctuations before and after the period of treatment.

Di-4S values had an average range of $246.3 \%$ (times baseline) across the three patients. For Patient 1 , the change from before PPS treatment to one week after treatment was negative, and for Patients 2 and 3, Di-4S increased with treatment. Across the three patients, DiHS-OS and DiHS-NS values had an average range of $147 \%$ and $167.3 \%$, respectively. Similar to Di- 4 S, HS disaccharides underwent a negative percent change for Patient 1 and a positive percent change for Patients 2 and 3. The average concentration range of monosulfated keratan sulfate (KS) and disulfated KS was $180.3 \%$ and $246.3 \%$, respectively. During PPS treatment in Patient 1, disulfated KS underwent a negative percent change, and monosulfated KS underwent a positive percent change. In Patient 2, both monosulfated KS and disulfated KS increased with PPS treatment. In Patient 3, these disaccharides decreased with treatment. For all three patients, urinary GAGs underwent dramatic fluctuations after PPS was discontinued.

For Patients 1 and 2, Di-4S was within mean + 2SD (normal range) at baseline; for Patient 3, Di-4S was above the normal range. These observations did not change with the PPS administration. In Patients 1 and 3, monosulfated KS stayed above and within the normal range, respectively, with treatment. Before, during, and after treatment, DiHS-NS and DiHS-OS was measured to be above the normal range in Patients 1 and 3. For Patient 2, DiHS-0S started within the normal range but was elevated with treatment [64]. The values of disulfated KS varied across all three patients. Results of the urinary GAG levels are summarized in Tables A3-A5 in the Appendix A.

\subsection{Serum GAG Levels}

As with urinary GAGs, large ranges of values were observed for serum GAGs. No clear trends were observed in all three patients. Additionally, it could not be concluded what kind of change, if any, was induced by PPS treatment, as serum GAG levels underwent dramatic fluctuations before and after the period of treatment.

Di-4S values had an average range of $130.3 \%$ (times baseline) across the three patients. For Patient 1 , the change from before PPS treatment to one week after treatment was positive, and for Patients 2 
and 3, Di-4S decreased with treatment. Across the three patients, DiHS-OS and DiHS-NS values had an average range of $91 \%$ and $107.7 \%$, respectively. In Patient 2, the percent change from before treatment to one week after the last PPS injection was positive for DiHS-OS and negative for DiHS-NS. HS disaccharides underwent a decrease in Patient 1 and an increase in Patient 3. The average concentration range of monosulfated KS and disulfated KS was $82.3 \%$ and 181\%, respectively. In Patients 1 and 2, disulfated KS underwent a negative percent change, and monosulfated KS underwent a positive percent change with treatment. Conversely, in Patient 3, monosulfated KS underwent a positive percent change, and disulfated KS underwent a negative percent change. For all three patients, serum GAGs underwent dramatic fluctuations after PPS was discontinued. In general, serum GAGs were initially measured within the normal range, and this was kept during and after treatment. There was, however, an exception observed for monosulfated KS: monosulfated KS was measured above the normal range at baseline, and this did not change with treatment [64]. Results of the serum GAG levels are summarized in Tables A6-A8 in the Appendix A.

\subsection{Serum Cytokine Levels}

Several pro-inflammatory cytokines measured during the trial changed with PPS treatment, these include MIF and TNF- $\alpha$. Of the two cytokines, only TNF- $\alpha$ levels were elevated above the normal range in the patients before treatment, and there was a trend towards a TNF- $\alpha$ decrease in all three patients, particularly in Patient 2. Of note, even though MIF levels were within or below the normal range at the start of treatment $\left(15.3-52.3 \times 10^{3} \mathrm{pg} / \mathrm{mL}\right)$, a trend towards reduction was also noted in the patients with PPS treatment. Again, Patient 2 showed the clearest response. For all other inflammatory cytokines measured, (VEGF, MCP-1, IL-1 $\beta$, IL-6, IL-8, IL-18, and TNFR1, and anti-inflammatory factor IL-10, no clear changes in the three patients were detected during treatment (). As depicted in Figure $1 \mathrm{a}-\mathrm{c}$, the levels generally decreased over time during PPS administration but did not continue to decrease after PPS was discontinued. The decrease in serum levels was most evident in Patient 2.

(a)
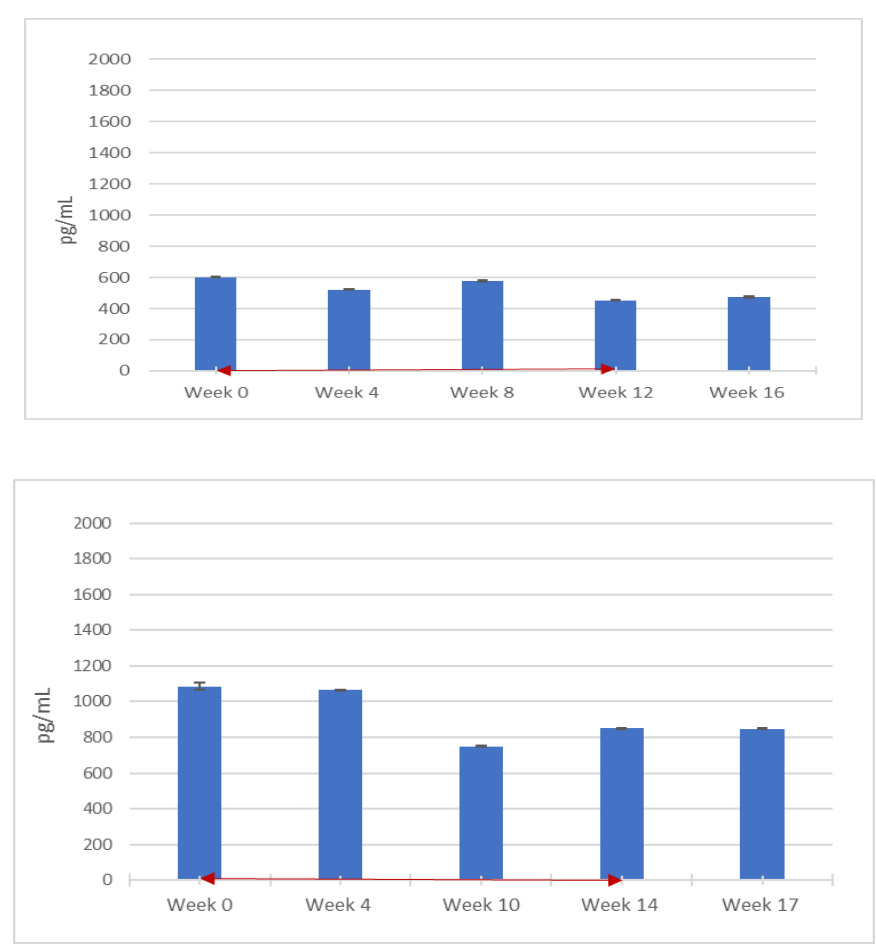

Figure 1. Cont. 
(c)

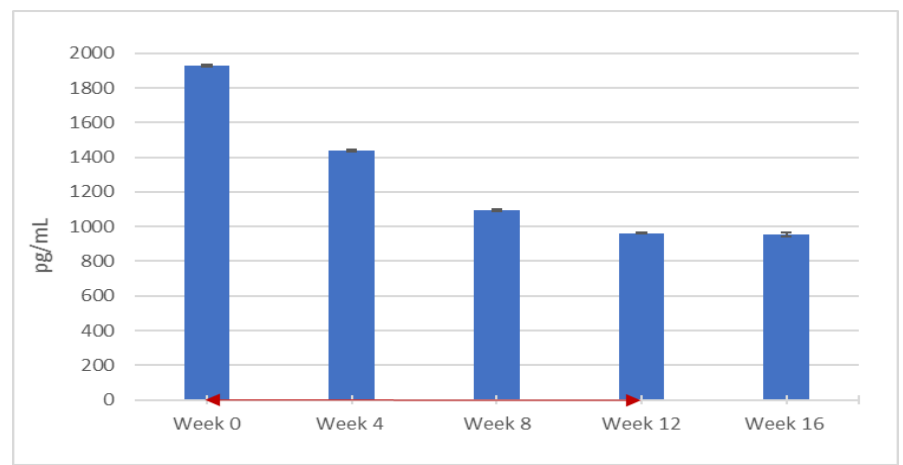

Figure 1. Blood serum migration inhibitory factor (MIF) levels throughout PPS treatment. Three adult males with attenuated MPS II were administered weekly PPS injections for 12 weeks at a dosage of $0.5 \mathrm{mg} / \mathrm{kg}$ for the first injection and $1.0 \mathrm{mg} / \mathrm{kg}$ for all subsequent injections. Patients 1,2 , and 3, are represented by (a), (b), and (c), respectively. Blood serum samples were measured for MIF levels using a human antibody enzyme-linked immunosorbent assay (ELISA) (R and D Systems) at the start of the clinical trial, before weekly PPS injections, and were then taken every 4 weeks for 16 weeks in Patients 2 and 3 before the injection. For Patient 1, measurements were taken at weeks 4, 10, 14, and 17, as a seizure occurred between injections 7 and 8 and treatment was halted for two weeks. Bars represent standard error of the mean $(n=3)$. The red, double-headed arrows indicate the start and end of the PPS injection period.

With regard to TNF- $\alpha$, the levels were markedly elevated above the normal range of $<15.6 \mathrm{pg} / \mathrm{mL}$ at week 0 in all three patients. According to Figure $2 a-c, T N F-\alpha$ underwent a notable decrease over time for Patients 1 and 2 but still remained above normal at the end of the trial period. There was also a transient increase at week 10 in Patient 1 . Only a very modest reduction in TNF- $\alpha$ was noted in Patient 3 (who, unlike the other patients, remained off ERT) during PPS treatment, and as with MIF, the most significant result was in Patient 2. After the last injection, levels continued to decrease in Patients 1 and 2. In Patient $3, \mathrm{TNF}-\alpha$ concentration reverted to the baseline value.

(a)
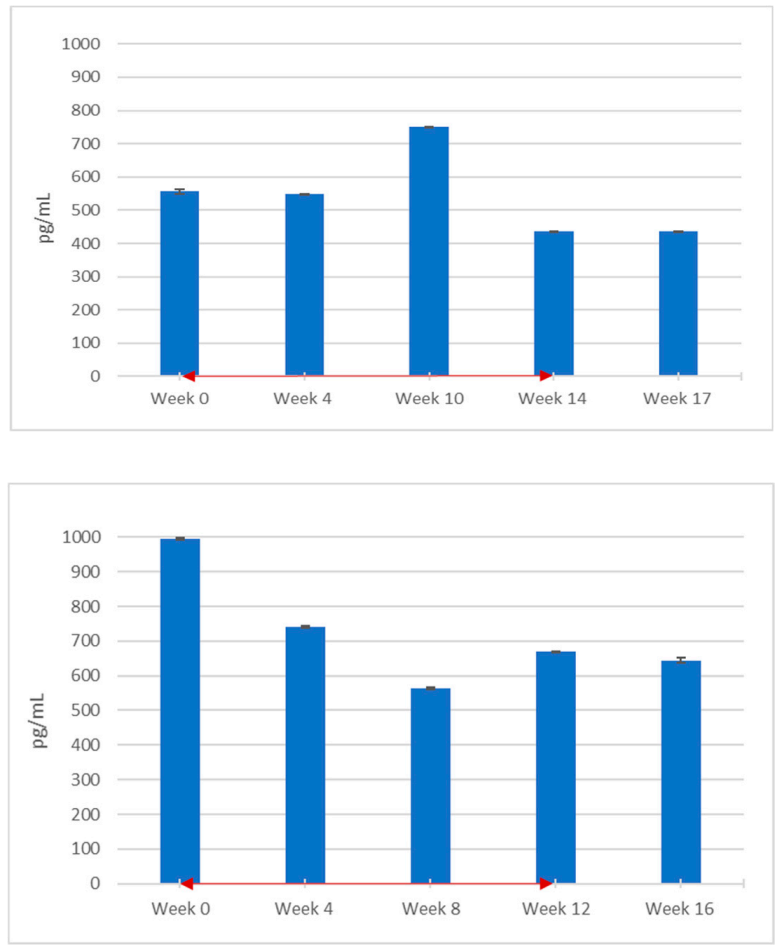

Figure 2. Cont. 


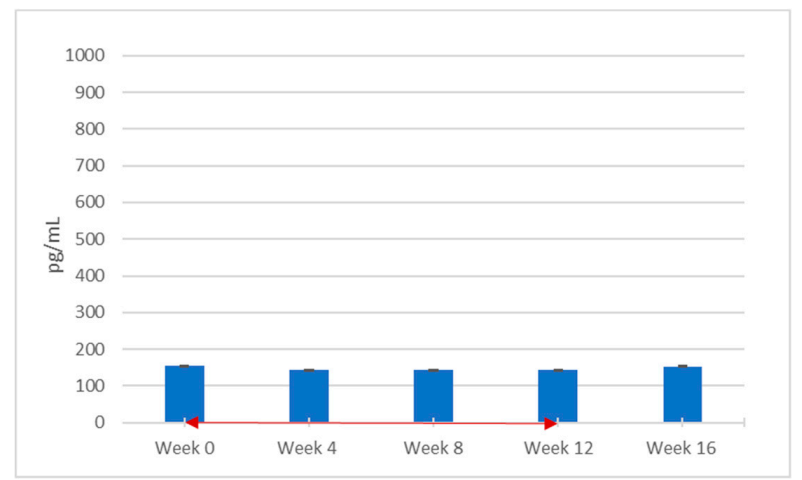

Figure 2. Blood serum tumor necrosis factor- $\alpha$ (TNF- $\alpha$ ) levels throughout PPS treatment. PPS injections were administered to 3 adult males with attenuated MPS II weekly for 12 weeks at a dosage of $0.5 \mathrm{mg} / \mathrm{kg}$ for the first injection and $1.0 \mathrm{mg} / \mathrm{kg}$ for all subsequent injections. Patients 1,2 , and 3 , are represented by (a), (b), and (c), respectively. Blood serum samples were measured for TNF- $\alpha$ levels using a human antibody ELISA ( $R$ and D Systems) at the start of the clinical trial, before weekly PPS injections and were then taken every 4 weeks for 16 weeks in Patients 2 and 3. For Patient 1, measurements were taken at weeks $4,10,14$, and 17, as a seizure occurred between injections 7 and 8 and treatment was halted for two weeks. Bars represent standard error of the mean $(n=3)$. The red, double-headed arrows indicate the start and end of the PPS injection period.

\section{Discussion}

The primary aim of this study was to evaluate the safety of weekly subcutaneous PPS administration in adult MPS II patients and to define clinical endpoints and biomarkers for further clinical trials. All patients in the study had attenuated MPS II. As listed in Table A1 in the Appendix A, the patients had different iduronate-2-sulfatase mutations. Several mutations ( $p$.Arg443Ter, $p$.Asp308Asn, and $p$.Cys171Arg) have been identified previously in attenuated MPS II [65-68]. p.Arg443Ter is a nonsense mutation in a CpG hot-spot of exon 9, and it involves an arginine residue [65]. Both p.Asp308Asn and p.Cys171Arg are missense mutations, the former is present in exon 7 [65-68].

Importantly, as in the previous six-month clinical study of attenuated MPS I patients, this study demonstrated an excellent safety profile of PPS in MPS II. As PPS is mainly processed in the liver and can be a weak anti-thrombotic agent [69], potential risks include abnormal coagulation, increased bleeding, and impaired hepatic function. Patient 3 did experience elevation of ALT, a measurement of liver malfunction, during PPS treatment. However, ALT stayed mostly within the normal range and decreased over time; therefore, this effect of PPS was determined to be mild and non-cumulative. There were no signs of abnormal coagulation or increased bleeding. Additionally, Patient 1 experienced convulsions, and injections were halted for two weeks; however, these convulsions were due to epilepsy unrelated to PPS administration. All patients continued treatment for the allotted 12 weeks and none had to withdraw due to adverse effects. No notable digestive, respiratory, cardiovascular, or neurological symptoms occurred with treatment, and this is emphasized by an abdominal CT scan, electrocardiogram, pulmonary function, brain MRI, and hearing and visual assessment results. These findings are significant as they support previous results in MPS I subjects and demonstrate safety in an additional MPS type, MPS II [57].

Given the very short time frame of the study (three months), we did not expect to observe clinical or pathologic improvements in the patients, and patients were not enrolled in the study based on the extent of their clinical or pathologic disabilities. Nonetheless, we did monitor several of these parameters throughout the study. For example, several parameters of skeletal pathology were assessed to determine the efficacy of PPS. Patient 1 experienced decreased knee pain and cartilage irregularity. In Patients 1 and 2, shoulder flexion, abduction, adduction, and inner rotation increased by a range of $6^{\circ}$ to $14^{\circ}, 30^{\circ}$ to $68^{\circ}, 17^{\circ}$ to $32^{\circ}$, and $41^{\circ}$ to $75^{\circ}$, respectively. However, these changes went unnoticed by the patients themselves, and all other parameters of shoulder ROM did not change or improve. 
Additionally, there were no improvements in the other tests for mobility (6MWT and 3SCT). Therefore, the findings suggest that PPS had relatively mild efficacy on MPS skeletal pathology during this three-month period. The results also suggest that this efficacy is strengthened when combined with ERT, as Patient 3, who remained off of ERT during PPS administration, experienced less improvement than Patients 1 and 2. It must be cautioned, however, that this was a very short duration-study in only three patients, and more clinical studies are required to assess efficacy.

Although there were mild improvements in skeletal pathology, changes in urine and serum glycosaminoglycans were inconclusive. No common trends were detected across the subjects of the study. Within both the period of treatment and recovery from treatment, patients experienced a great range of GAG levels with respect to baseline. Furthermore, there was often significant variation detected between consecutive time points. These two factors made it difficult to conclude whether a specific GAG (serum or urine) increased or decreased with treatment. This is a notable limitation of the study and is most likely due to the short time frame in which GAG levels were measured and/or individual variability that is particularly emphasized due to the small sample size. As the hallmark of MPS is GAG storage and excretion, and GAG tissue, blood, and urine levels have been used as a biomarker to assess therapeutic efficacy, future studies should utilize a longer treatment and recovery time to allow for the possible action of PPS to take full effect. In addition, a larger sample with wild-type controls should be used to conduct more in-depth statistical analysis when determining the effect of PPS on this parameter of MPS pathology.

Hennermann et al. previously evaluated the effects of PPS injections (at 1 or $2 \mathrm{mg} / \mathrm{kg}$ ) on four adult patients with MPS I treated for six months in combination with ERT [57]. It was found that there was no significant change in total urinary GAG concentration after 12 weeks of treatment. However, after 24 weeks, total GAG concentrations decreased significantly to near normal values in all four patients [57]. These findings suggest that we may observe a decrease in GAG levels of the MPS II patients if PPS injections are continued for a longer time and/or are administered to patients at higher concentrations. It should also be noted that Hennermann et al. measured total urine GAGs in patients with MPS I [57], while we measured the individual GAG-related disaccharides. As stated before, future studies should assess the efficacy of PPS over a longer period of treatment and recovery time to determine whether administration leads to stabilization and/or a decrease of GAG levels. It is likely that a longer course of treatment is needed to conclusively evaluate clinical changes.

The anti-inflammatory effects of PPS have been extensively documented, and broad anti-inflammatory effects were previously studied in three MPS animal models [52-54,56], and also in cells from Fabry and Gaucher disease patients treated with PPS [55]. Several cytokines related to inflammation were also measured during the current trial. MIF and TNF- $\alpha$ levels generally decreased with treatment for all three patients, with Patient 2 responding the most. It should be noted that MIF levels were never elevated above normal range in any of the patients, even at the start of PPS treatment. Also, TNF- $\alpha$ levels, while reduced, did not reach normal levels. The latter observation could be due to the short duration of treatment (three months) and/or the dose of PPS that was administered. It should also be noted that we saw an elevation of cytokine levels when PPS treatment was stopped. Overall, there were decreases observed in TNF- $\alpha$ and MIF with PPS treatment and few changes in any of the other cytokines measured. Additionally, this decrease in TNF- $\alpha$ and MIF was milder in Patient 3, suggesting that the anti-inflammatory activity of PPS in joints might be strengthened when used concurrently with ERT.

The mechanism by which inflammation occurs in MPS has not been fully elucidated, and a hierarchy of relevant cytokines has not yet been fully determined. Out of cytokines studied here, only TNF- $\alpha$ has been implicated in MPS. In the context of the disease, TNF- $\alpha$ contributes greatly to bone pathology [70]. MIF is commonly categorized as pro-inflammatory, like TNF- $\alpha$ [71]; however, unlike TNF- $\alpha$, it has not been implicated in MPS. Overall, more research with an increased number of patients for a longer period of time is needed to fully establish relationships between PPS treatment, 
inflammation, and improvement in MPS physiology. It is noteworthy that ROM and pro-inflammatory factors might be useful clinical endpoints and biomarkers respectively, for Phase II/III clinical trials.

Currently, several other agents are being tested for the treatment of MPS, in addition to PPS and ERT. For example, treatment with rhodamine B led to an improvement in behavioral tests for MPS IIIA [72] and MPS I [73] mice, which indicates that rhodamine B has the potential to cross the blood-brain barrier to improve CNS function. It is hypothesized to work as a non-specific inhibitor of GAG synthesis [74]. Not much is known about Odiparcil ${ }^{\circledR}$, but clinical trials are being conducted by Inventiva, testing the agent's potential as a treatment for MPS VI. Perhaps the most prevalent of the available substrate reduction agents is genistein, which works by regulating expression of GAG synthesis genes [75,76]; genistein has also demonstrated the potential to improve cell cycle defects characteristic of MPS II [77]. Similar to rhodamine B, genistein can cross the blood-brain barrier [41,42].

Among the various experimental therapies being studied in MPS, PPS is somewhat unique since it not only reduces GAG storage but also significantly reduces inflammatory cytokines in MPS animal models. It also appears to cross the blood-brain barrier, although this has only been studied in the context of one neurological MPS model (MPS IIIA) [56]. There is extensive clinical data in different diseases showing the safety of PPS administration in humans, and now seven MPS patients of two different types have been treated (4 MPS I and 3 MPS II) without serious, drug-related adverse events. Thus, we propose that PPS is a very attractive drug that should be studied further in MPS and other lysosomal storage diseases.

In conclusion, this study established the safety and analyzed the potential effectiveness of PPS treatment in three adult male patients with MPS II. There was no serious adverse effect noted throughout PPS treatment, indicating that weekly PPS treatment can be safely used in adults with MPS II. Furthermore, this study has shown that PPS treatment may decrease pro-inflammatory cytokines that are implicated in MPS physiology. Further research should be conducted to fully elucidate the mechanism by which PPS works to decrease inflammation and to confirm its treatment efficacy as a GAG-reducing agent. In the future, testing should be performed over a longer course of time and with a broader range of subjects, including in children, as early intervention is critical in MPS.

Author Contributions: The authors contributed as follows; conceptualization, K.O., S.T., Y.S., C.M.S., E.H.S., T.F. and T.M.; methodology, K.O., S.T., M.S. and T.M.; software, K.O., A.L., S.T. and T.M.; validation, K.O., S.T., M.S., and T.M.; formal analysis, K.O., A.L., S.T. and T.M.; investigation, K.O., A.L., S.T., M.S. and T.M.; resources, K.O., S.T. and T.M.; data curation, K.O., S.T. and T.M.; writing-original draft preparation, K.O., A.L. and S.T.; writing-review and editing, K.O., A.L., S.T., M.S., Y.S., C.M.S., E.H.S., T.F. and T.M.; supervision, S.T. and T.F.; project administration, K.O., S.T. and T.M.; funding acquisition, S.T. and T.M.

Funding: This work was supported by NEDO/New Energy and Industrial Technology Development Organization (Grant Number: 15664153). This work was also supported by grants from The Carol Ann Foundation, Angelo R. Cali and Mary V. Cali Family Foundation, Inc., The Vain and Harry Fish Foundation, Inc., The Bennett Foundation, Jacob Randall Foundation, Austrian and Japanese MPS societies, and Nemours Funds. The content of the article has not been influenced by the sponsors. The content is solely the responsibility of the authors and does not necessarily represent the official views of NEDO. We are grateful to Kyoko Nakazato for editorial assistance and for the critical reading of the manuscript.

Conflicts of Interest: CMS and EHS are co-inventors on patents related to the treatment of MPS disorders with PPS. These patents have been licensed to ReqMed and another company. T.M. is an employee of ReqMed.

\section{Abbreviations}

$\begin{array}{ll}\text { MPS } & \text { Mucopolysaccharidoses } \\ \text { GAG } & \text { glycosaminoglycan } \\ \text { ECM } & \text { extracellular matrix } \\ \text { HS } & \text { heparan sulfate } \\ \text { DS } & \text { dermatan sulfate } \\ \text { ERT } & \text { enzyme replacement therapy } \\ \text { HSCT } & \text { hematopoietic stem cell therapy } \\ \text { FDA } & \text { Food and Drug Administration }\end{array}$


SRT

PPS

TLR4

TNF- $\alpha$

IL-1 $\beta$

IL-8

MIP-1 $\alpha$

IL-6

WBC

AST

ALT

APTT

6MWT

3MSCT

ROM

UCG

MRI

CT

ABR

LC-MS/MS

KS

ELISA

MIF

VEGF

IL-10

IL-18

MCP-1

TNFR1

EEG

N/A

VC

TD

FEV1

PEF

V.50

substrate reduction therapy

pentosan polysulfate

toll-like receptor 4

tumor necrosis factor- $\alpha$

interleukin- $1 \beta$

interleukin-8

macrophage inflammatory protein $-1 \alpha$

interleukin-6

white blood cell

aspartate aminotransferase

alanine transaminase

activated partial thromboplastin time

6-minute walk test

3-minute stair climb test

range of motion

ultrasonic cardiography

magnetic resonance imaging

computer tomography

auditory brainstem response

liquid chromotraphy-tandem mass spectrometry

keratan sulfate

enzyme-linked immunosorbent assay

macrophage migration inhibitory factor

vascular endothelial growth factor

interleukin-10

interleukin-18

macrophage migration inhibitory factor

tumor necrosis factor receptor 1

electroencephalography

not applicable

vital capacity

tidal volume

forced expiratory volume per second

peak expiratory flow

maxixmal flow rate of expiration at $50 \%$ vital capacity

\section{Appendix A}

Table A1. MPS II Patient Demographics.

\begin{tabular}{cccc}
\hline & Patient 1 & Patient 2 & Patient 3 \\
\hline Age & 22 years old & 34 years old & 37 years old \\
Height & $135.6 \mathrm{~cm}$ & $118.2 \mathrm{~cm}$ & $169.0 \mathrm{~cm}$ \\
Weight & $43.9 \mathrm{~kg}$ & $34.5 \mathrm{~kg}$ & $58.0 \mathrm{~kg}$ \\
Sex & Male & Male & Male \\
Iduronate-2-sulfatase & $p$.Cys1326Thr & $p$. Gly922AlaG922A & $p$.Thr511Cys \\
Mutations & $p$. Arg443X & $p$. Asp308Asn & $p$.Cys171Arg \\
ERT Status & With ERT & With ERT & Without ERT \\
\hline
\end{tabular}


Table A2. Parameters to Assess for Adverse Effects of PPS Treatment in MPS II.

\begin{tabular}{|c|c|c|c|c|c|c|}
\hline & \multicolumn{2}{|c|}{ Patient 1} & \multicolumn{2}{|l|}{ Patient 2} & \multicolumn{2}{|c|}{ Patient 3} \\
\hline & Before & After & Before & After & Before & After \\
\hline $\begin{array}{c}\text { Pulmonary Function } \\
\text { Test }\end{array}$ & \multicolumn{2}{|c|}{ Restrictive } & \multicolumn{2}{|c|}{ Restrictive and obstructive } & \multicolumn{2}{|c|}{ Normal } \\
\hline Vital Capacity (VC) & 1.66 & 1.74 & 1.02 & & 4.09 & 4.12 \\
\hline Tidal Volume (TV) & 0.48 & 0.56 & 0.2 & & 0.56 & 0.77 \\
\hline \multicolumn{7}{|l|}{ Forced Expiratory } \\
\hline $\begin{array}{l}\text { Volume/Second } \\
\text { (FEV1) }\end{array}$ & 1.27 & 1.34 & 0.63 & & 3.38 & 3.35 \\
\hline FEV1/VC & $79.37 \%$ & $78.33 \%$ & $67.74 \%$ & & $83.40 \%$ & $82.10 \%$ \\
\hline $\begin{array}{l}\text { Peak Expiratory Flow } \\
\text { (PEF) }\end{array}$ & 2.86 & 2.99 & 1.85 & & Not available & Not available \\
\hline $\begin{array}{l}\text { Maximal Flow Rate of } \\
\text { Expiration at } 50 \% \text { VC } \\
\text { (V.50) }\end{array}$ & 1.54 & 1.43 & 0.66 & & Not available & Not available \\
\hline Electrocardiogram & Mild left ventricle hypertrophy & No change & $\begin{array}{l}\text { PR prolongation, high amplitude } \\
\text { of V5 and V6, T-wave flattening }\end{array}$ & No change & Normal & Normal \\
\hline \multirow[t]{2}{*}{ Echocardiogram } & $\begin{array}{l}\text { Left Atrial to Aortic Root Ratio: } \\
\text { 1.31, Ejection Fraction: } 66.6 \%\end{array}$ & $\begin{array}{c}\text { Left Atrial to Aortic Root } \\
\text { Ratio: 1.3, Ejection Fraction } \\
64.5 \%\end{array}$ & Ejection Fraction: $67 \%$ & $\begin{array}{l}\text { Ejection } \\
\text { Fraction: } 63 \%\end{array}$ & Not available & Not available \\
\hline & $\begin{array}{l}\text { tricuspid regurgitation, } \\
\text { pulmonary regurgitation, } \\
\text { mitral regurgitation }\end{array}$ & No change & $\begin{array}{l}\text { left ventricular enlargement, } \\
\text { tricuspid regurgitation, aortic } \\
\text { regurgitation, mitral } \\
\text { regurgitation }\end{array}$ & No change & $\begin{array}{l}\text { aortic valvular } \\
\text { hypertrophy, aortic } \\
\text { regurgitation }\end{array}$ & No change \\
\hline Hearing test & $\begin{array}{l}\text { Right:55dB } \\
\text { Left:53dB }\end{array}$ & No change & $\begin{array}{l}\text { Right: } 73 \mathrm{~dB} \\
\text { Left: } 75 \mathrm{~dB}\end{array}$ & No change & Not available & Not available \\
\hline Visual test & Retinitis pigmentosa & No change & $\begin{array}{l}\text { Retinitis pigmentosa, } \\
\text { Visual field defect }\end{array}$ & No change & $\begin{array}{l}\text { Retinitis pigmentosa, } \\
\text { Manual vision }\end{array}$ & $\begin{array}{c}\text { Retinitis pigmentosa, } \\
\text { Manual vision }\end{array}$ \\
\hline \multirow[t]{3}{*}{ Brain MRI } & $\begin{array}{l}\text { Bilateral diffuse white matter } \\
\text { high signal }\end{array}$ & No change & $\begin{array}{l}\text { Bilateral diffuse white matter } \\
\text { high signal }\end{array}$ & No change & $\begin{array}{l}\text { Bilateral diffuse white } \\
\text { matter high signal }\end{array}$ & No change \\
\hline & $\begin{array}{l}\text { Perivascular dilation in } \\
\text { subcortical white matter }\end{array}$ & No change & $\begin{array}{l}\text { Perivascular dilation in } \\
\text { subcortical white matter }\end{array}$ & No change & $\begin{array}{l}\text { Perivascular dilation in } \\
\text { subcortical white matter }\end{array}$ & No change \\
\hline & $\begin{array}{l}\text { Enlargement of bilateral } \\
\text { ventricles }\end{array}$ & No change & $\begin{array}{c}\text { Diffuse patchy high signal in } \\
\text { bilateral thalamus, basal nucleus, } \\
\text { midbrain, and pons }\end{array}$ & No change & & \\
\hline Abdominal CT & No hepatosplenomegaly & No change & No hepatosplenomegaly & No change & No hepatosplenomegaly & No change \\
\hline
\end{tabular}


Table A3. Urinary DS levels over the course of PPS treatment with respect to baseline concentration ${ }^{\mathrm{a}}$.

\begin{tabular}{|c|c|c|c|}
\hline & Patient 1 & Patient 2 & Patient 3 \\
\hline & Di-4S & Di-4S & Di-4S \\
\hline Range during Treatment & $-55 \%$ to $95 \%$ & $112 \%$ to $538 \%$ & $-99 \%$ to $64 \%$ \\
\hline Overall Change with Treatment ${ }^{b}$ & $-70 \%$ & $109 \%$ & $44 \%$ \\
\hline \multirow{2}{*}{ Changes after Treatment ${ }^{c}$} & Increase to $165 \%$ & Decrease to $-8 \%$ & Increase to $112 \%$ \\
\hline & Decrease to $-31 \%$ & Increase to $954 \%$ & Decrease to $-23 \%$ \\
\hline
\end{tabular}

Table A4. Urinary HS levels over the course of PPS treatment with respect to baseline concentration ${ }^{\text {a }}$.

\begin{tabular}{|c|c|c|c|c|c|c|}
\hline & \multicolumn{2}{|c|}{ Patient 1} & \multicolumn{2}{|c|}{ Patient 2} & \multicolumn{2}{|c|}{ Patient 3} \\
\hline & DiHS-0S & DiHS-NS & DiHS-0S & DiHS-NS & DiHS-0S & DiHS-NS \\
\hline $\begin{array}{l}\text { Range during } \\
\text { Treatment }\end{array}$ & $-32 \%$ to $38 \%$ & $-38 \%$ to $35 \%$ & $44 \%$ to $185 \%$ & $12 \%$ to $240 \%$ & $-100 \%$ to $130 \%$ & $-99 \%$ to $102 \%$ \\
\hline $\begin{array}{l}\text { Overall Change } \\
\text { with Treatment }{ }^{b}\end{array}$ & $-5 \%$ & $-45 \%$ & $97 \%$ & $151 \%$ & $17 \%$ & $17 \%$ \\
\hline $\begin{array}{c}\text { Changes after } \\
\text { Treatment }{ }^{c}\end{array}$ & $\begin{array}{c}\text { Increase to } 39 \% \\
\text { Decrease to }-16 \%\end{array}$ & $\begin{array}{c}\text { Increase to } 30 \% \\
\text { Decrease to }-41 \%\end{array}$ & $\begin{array}{l}\text { Decrease to }-15 \% \\
\text { Increase to } 225 \%\end{array}$ & $\begin{array}{l}\text { Decrease to }-18 \% \\
\text { Increase to } 493 \%\end{array}$ & $\begin{array}{l}\text { Increase to } 94 \% \\
\text { Decrease to }-3 \%\end{array}$ & $\begin{array}{c}\text { Increase to } 87 \% \\
\text { Decrease to }-29 \%\end{array}$ \\
\hline
\end{tabular}

Table A5. Urinary KS levels over the course of PPS treatment with respect to baseline concentration ${ }^{\mathrm{a}}$.

\begin{tabular}{|c|c|c|c|c|c|c|}
\hline & \multicolumn{2}{|c|}{ Patient 1} & \multicolumn{2}{|c|}{ Patient 2} & \multicolumn{2}{|c|}{ Patient 3} \\
\hline & Di-KS & Mono-KS & Di-KS & Mono-KS & Di-KS & Mono-KS \\
\hline $\begin{array}{c}\text { Range during } \\
\text { Treatment }\end{array}$ & $-70 \%$ to $147 \%$ & $-77 \%$ to $-37 \%$ & $25 \%$ to $289 \%$ & $18 \%$ to $398 \%$ & $-94 \%$ to $164 \%$ & $-84 \%$ to $37 \%$ \\
\hline $\begin{array}{l}\text { Overall Change } \\
\text { with Treatment }\end{array}$ & $82 \%$ & $-71 \%$ & $75 \%$ & $153 \%$ & $-24 \%$ & $-36 \%$ \\
\hline Changes after & Increase to $175 \%$ & Increase to 3\% & Decrease to $42 \%$ & Decrease to $36 \%$ & Increase to $99 \%$ & Increase to $30 \%$ \\
\hline
\end{tabular}

Treatment ${ }^{c} \quad$ Decrease to $42 \% \quad$ Decrease to $-61 \% \quad$ Increase to $230 \% \quad$ Increase to $257 \% \quad$ Decrease to $18 \% \quad$ Decrease to $27 \%$

a Baseline concentration refers to disaccharide concentration measured before PPS was administered. For example, $82 \%$ indicates the value measured at a time point was $82 \%$ below baseline. ${ }^{b}$ Overall change with treatment was determined by calculating the percent change between baseline value and the value measured one week after the last injection. ${ }^{c}$ Changes after treatment refer to observations made from one week to four weeks after the last injection.

Table A6. Serum DS levels over the course of PPS treatment with respect to baseline concentration ${ }^{\mathrm{a}}$.

\begin{tabular}{|c|c|c|c|}
\hline & Patient 1 & Patient 2 & Patient 3 \\
\hline & Di-4S & $\mathrm{Di}-4 \mathrm{~S}$ & $\mathrm{Di}-4 \mathrm{~S}$ \\
\hline Range during Treatment & $-56 \%$ to $54 \%$ & $-78 \%$ to $28 \%$ & $-45 \%$ to $130 \%$ \\
\hline Overall Change with Treatment ${ }^{b}$ & $96 \%$ & $-45 \%$ & $-47 \%$ \\
\hline \multirow{3}{*}{ Changes after Treatment ${ }^{c}$} & Decrease to $-23 \%$ & Increase to $-18 \%$ & Increase to $13 \%$ \\
\hline & Increase to $37 \%$ & Decrease to $-44 \%$ & Decrease to $3 \%$ \\
\hline & Decrease to $-16 \%$ & Increase $-29 \%$ & Increase to $39 \%$ \\
\hline
\end{tabular}

${ }^{a}$ Baseline concentration refers to disaccharide concentration measured before PPS was administered. For example, $96 \%$ indicates the value measured at a time point was $96 \%$ above baseline. ${ }^{b}$ Overall change with treatment was determined by calculating the percent change between baseline value and the value measured one week after the last injection. ${ }^{c}$ Changes after treatment refer to observations made from one week to four weeks after the last injection. 
Table A7. Serum HS levels over the course of PPS treatment with respect to baseline concentration ${ }^{\mathrm{a}}$.

\begin{tabular}{|c|c|c|c|c|c|c|}
\hline & \multicolumn{2}{|c|}{ Patient 1} & \multicolumn{2}{|c|}{ Patient 2} & \multicolumn{2}{|c|}{ Patient 3} \\
\hline & DiHS-0S & DiHS-NS & DiHS-0S & DiHS-NS & DiHS-0S & DiHS-NS \\
\hline $\begin{array}{l}\text { Range during } \\
\text { Treatment }\end{array}$ & $-53 \%$ to $18 \%$ & $-52 \%$ to $76 \%$ & $-38 \%$ to $-5 \%$ & $-44 \%$ to $19 \%$ & $-42 \%$ to $127 \%$ & $-54 \%$ to $78 \%$ \\
\hline $\begin{array}{l}\text { Overall Change } \\
\text { with Treatment } b\end{array}$ & $-16 \%$ & $-152 \%$ & $13 \%$ & $-21 \%$ & $22 \%$ & $32 \%$ \\
\hline $\begin{array}{l}\text { Changes after } \\
\text { Treatment }{ }^{c}\end{array}$ & $\begin{array}{c}\text { Decrease to }-24 \% \\
\text { Increase to } 13 \%\end{array}$ & $\begin{array}{l}\text { Decrease to } 61 \% \\
\text { Increase to } 96 \%\end{array}$ & $\begin{array}{l}\text { Decrease to }-18 \% \\
\text { Increase to } 33 \%\end{array}$ & $\begin{array}{l}\text { Increase to }-9 \% \\
\text { Decrease to }-47 \% \\
\text { Increase to }-32 \%\end{array}$ & $\begin{array}{l}\text { Increase to } 61 \% \\
\text { Decrease to } 21 \% \\
\text { Increase to } 67 \%\end{array}$ & $\begin{array}{l}\text { Decrease to } 10 \% \\
\text { Increase to } 71 \%\end{array}$ \\
\hline
\end{tabular}

a Baseline concentration refers to disaccharide concentration measured before PPS was administered. For example, $-16 \%$ indicates the value measured at a time point was $16 \%$ below baseline. ${ }^{b}$ Overall change with treatment was determined by calculating the percent change between baseline value and the value measured one week after the last injection. ${ }^{c}$ Changes after treatment refer to observations made from one week to four weeks after the last injection.

Table A8. Serum KS levels over the course of PPS treatment with respect to baseline concentration ${ }^{\text {a }}$.

\begin{tabular}{|c|c|c|c|c|c|c|}
\hline & \multicolumn{2}{|c|}{ Patient 1} & \multicolumn{2}{|c|}{ Patient 2} & \multicolumn{2}{|c|}{ Patient 3} \\
\hline & Di-KS & Mono-KS & Di-KS & Mono-KS & Di-KS & Mono-KS \\
\hline $\begin{array}{l}\text { Range during } \\
\text { Treatment }\end{array}$ & $-73 \%$ to $215 \%$ & $-45 \%$ to $20 \%$ & $-43 \%$ to $2 \%$ & $-19 \%$ to $9 \%$ & $-43 \%$ to $167 \%$ & $-60 \%$ to $94 \%$ \\
\hline $\begin{array}{l}\text { Overall Change } \\
\text { with Treatment }{ }^{b}\end{array}$ & $-36 \%$ & $23 \%$ & $-3 \%$ & $18 \%$ & $48 \%$ & $-51 \%$ \\
\hline $\begin{array}{c}\text { Changes after } \\
\text { Treatment }{ }^{c}\end{array}$ & $\begin{array}{l}\text { Increase to }-24 \% \\
\text { Decrease to }-61 \%\end{array}$ & $\begin{array}{c}\text { Increase to } 30 \% \\
\text { Decrease to }-16 \%\end{array}$ & $\begin{array}{l}\text { Decrease to }-28 \% \\
\text { Increase to }-22 \%\end{array}$ & $\begin{array}{l}\text { Decrease to }-16 \% \\
\text { Increase to }-7 \%\end{array}$ & $\begin{array}{c}\text { Increase to } 68 \% \\
\text { Decrease to }-19 \% \\
\text { Increase to }-3 \%\end{array}$ & $\begin{array}{l}\text { Increase to } 3 \% \\
\text { Decrease to }-21 \% \\
\text { Increase to } 42 \%\end{array}$ \\
\hline
\end{tabular}

a Baseline concentration refers to disaccharide concentration measured before PPS was administered. For example, $-5 \%$ indicates the value measured at a time point was $5 \%$ below baseline. ${ }^{b}$ Overall change with treatment was determined by calculating the percent change between baseline value and the value measured one week after the last injection. ${ }^{\mathrm{c}}$ Changes after treatment refer to observations made from one week to four weeks after the last injection.

\section{References}

1. Wraith, J.E. The mucopolysaccharidoses: A clinical review and guide to management. Arch. Dis. Child. 1995, 72, 263-267. [CrossRef] [PubMed]

2. Applegarth, D.A.; Toone, J.R.; Lowry, R.B. Incidence of inborn errors of metabolism in British Columbia, 1969-1996. Pediatrics. 2000. [CrossRef] [PubMed]

3. Baehner, F.; Schmiedeskamp, C.; Krummenauer, F.; Miebach, E.; Bajbouj, M.; Whybra, C.; Kohschutter, A.; Kampann, C. Cumulative incidence rates of the mucopolysaccharidoses in Germany. J. Inherit. Metab. Dis. 2005, 28, 1011-1017. [CrossRef] [PubMed]

4. Meikle, P.J.; Hopwood, J.J.; Clague, A.E.; Carey, W.F. Prevalence of lysosomal storage disorders. JAMA 1999, 281, 249-254. [CrossRef] [PubMed]

5. Nelson, J. Incidence of the mucopolysaccharidoses in Northern Ireland. Hum. Genet. 1997, 101, $355-358$. [CrossRef] [PubMed]

6. Nelson, J.; Crowhurst, J.; Carey, B.; Greed, L. Incidence of the mucopolysaccharidoses in Western Australia. Am. J. Med. Genet. A. 2003, 123A, 310-313. [CrossRef] [PubMed]

7. Poorthuis, B.J.; Wevers, R.A.; Kleijer, W.J.; Groener, J.E.; de Jong, J.G.; van Weely, S.; Niezen-Koning, K.E.; van Diggelen, O.P. The frequency of lysosomal storage diseases in The Netherlands. Hum. Genet. 1999, 105, 151-156. [CrossRef]

8. $\quad$ Lin, H.Y.; Lin, S.P.; Chuang, C.K.; Niu, D.M.; Chen, M.R.; Tsai, F.J.; Chao, M.C.; Chiu, P.C.; Lin, S.J.; Tsai, L.P.; et al. Incidence of the mucopolysaccharidoses in Taiwan. Am. J. Med. Genet. 2009, 149A, 960-964. [CrossRef] [PubMed]

9. Pinto, L.L.; Vieira, T.A.; Giugliani, R.; Schwartz, I.V. Expression of the disease on female carriers of X-linked lysosomal disorders: A brief review. OrphanetJ. Rare. Dis. 2010, 28, 14. [CrossRef]

10. Neufeld, E.F.; Muenzer, J. The mucopolysaccharidoses. In The Metabolic and Molecular Bases of Inherited Disease, 8th ed.; Scriver, C.R., Baudet, A.L., Sly, W.S., Valle, D., Childs, B., Kinzler, K.W., Vogelstein, B., Eds.; McGrawHill: New York, NY, USA, 2001; pp. 3421-3452.

11. Martin, R.; Beck, M.; Eng, C.; Giugliani, R.; Harmatz, P.; Muñoz, V.; Muenzer, J. Recognition and diagnosis of mucopolysaccharidosis II (Hunter syndrome). Pediatrics 2008, 121, 377-386. [CrossRef] 
12. Coutinho, M.F.; Santos, J.I.; Alves, S. Less is more: Substrate reduction therapy for lysosomal storage disorders. Int. J. Mol. Sci. 2016, 17, 1065. [CrossRef] [PubMed]

13. Wraith, J.E.; Beck, M.; Lane, R.; van der Ploeg, A.; Shapiro, E.; Xue, Y.; Kakkis, E.D.; Guffon, N. Enzyme replacement therapy in patients who have mucopolysaccharidosis I and are younger than 5 years: Results of a multinational study of recombinant human $\alpha$-L-iduronidase (laronidase). Pediatrics. 2007, 120, $37-46$. [CrossRef] [PubMed]

14. Wraith, J.E.; Clarke, L.A.; Beck, M.; Kolodny, E.H.; Pastores, G.M.; Muenzer, J.; Rapoport, D.M.; Berger, K.I.; Swiedler, S.J.; Kakkis, E.D.; et al. Enzyme replacement therapy for mucopolysaccharidosis I: A randomized, double-blinded, placebo-controlled, multinational study of recombinant human alpha-L-iduronidase (laronidase). J. Pediatr. 2004, 144, 581-588. [CrossRef] [PubMed]

15. Kishnani, P.S.; Corzo, D.; Leslie, N.D.; Gruskin, D.; Van der Ploeg, A.; Clancy, J.P.; Parini, R.; Morin, G.; Beck, M.; Bauer, M.S.; et al. Early treatment with alglucosidase alpha prolongs long-term survival of infants with Pompe disease. Pediatr. Res. 2009, 66, 329-335. [CrossRef] [PubMed]

16. Deegan, P.B. Fabry disease, enzyme replacement therapy and the significance of antibody responses. J. Inherit. Metab. Dis. 2012, 35, 227-243. [CrossRef] [PubMed]

17. Pastores, G.M.; Rosenbloom, B.; Weinreb, N.; Goker-Alpan, O.; Grabowski, G.; Cohn, G.M.; Zahrieh, D. A multicenter open-label treatment protocol (HGT-GCB-058) of velaglucerase alfa enzyme replacement therapy in patients with Gaucher disease type 1: Safety and tolerability. Genet. Med. 2014, 16, 359-366. [CrossRef] [PubMed]

18. Noh, H.; Lee, J.I. Current and potential therapeutic strategies for mucopolysaccharidoses. J. Clin. Pharm. 2014, 39, 215-224. [CrossRef]

19. Guffon, N.; Souillet, G.; Maire, I.; Straczek, J.; Guibaud, P. Follow-up of nine patients with Hurler syndrome after bone marrow transplantation. J. Pediatr. 1998, 133, 119-125. [CrossRef]

20. Krivit, W.; Pierpont, M.E.; Ayaz, K.; Tsai, M.; Ramsay, N.K.; Kersey, J.H.; Weisdorf, S.; Sibley, R.; Snover, D.; Mcgovern, M.M.; et al. Bone-marrow transplantation in the Maroteaux-Lamy syndrome (mucopolysaccharidosis type VI). N. Engl. J. Med. 1984, 311, 1606-1611. [CrossRef]

21. Prasad, V.K.; Kurtzberg, J. Transplant outcomes in mucopolysaccharidoses seminars in hematology. Semin. Hematol. 2010, 47, 59-69. [CrossRef]

22. Souillet, G.; Guffon, N.; Maire, I.; Pujol, M.; Taylor, P.; Sevin, F.; Bleyzac, N.; Mulier, C.; Durin, A.; Keballi, K.; et al. Outcome of 27 patients with Hurler's syndrome transplanted from either related or unrelated haematopoietic stem cell sources. Bone Marrow Transpl. 2003, 13, 1105-1117. [CrossRef] [PubMed]

23. Barth, A.L.; de Magalhaes, T.S.P.C.; Reis, A.B.R.; de Oliveira, M.L.; Scalco, F.B.; Cavalcanti, N.C.; Silva, D.S.E.; Torres, D.A.; Costa, A.A.P.; Bonfim, C.; et al. Early hematopoietic stem cell transplantation in a patient with severe mucopolysaccharidosis II: A 7 years follow-up. Mol. Genet. Metab. Rep. 2017, 12, 62-68. [CrossRef] [PubMed]

24. Boelens, J.J. Trends in haematopoietic cell transplantation for inborn errors of metabolism. J. Inherit. Metab. Dis. 2006, 29, 413-420. [CrossRef] [PubMed]

25. Chinen, Y.; Higa, T.; Tomatsu, S.; Suzuki, Y.; Orii, T.; Hyakuna, N. Long-term therapeutic efficacy of allogenic bone marrow transplantation in a patient with mucopolysaccharidosis IVA. Mol. Genet. Metab. Rep. 2014, 1, 31-41. [CrossRef] [PubMed]

26. Kubaski, F.; Yabe, H.; Suzuki, Y.; Seto, T.; Hamazaki, T.; Mason, R.W.; Xie, L.; Onsten, T.G.H.; Leistner-Segal, S.; Giugliani, R.; et al. Hematopoetic stem cell transplantation for patients with mucopolysaccharidosis II. Biol. Blood Marrow Transplant. 2017, 23, 1795-1803. [CrossRef] [PubMed]

27. Martin, P.L.; Carter, S.L.; Kernan, N.A.; Sahdev, I.; Wall, D.; Pietryga, D.; Wagner, J.E.; Kurtzberg, J. Results of the cord blood transplantation study (COBLT): Outcomes of unrelated donor umbilical cord blood transplantation in pediatric patients with lysosomal and peroxisomal storage diseases. Biol. Blood Marrow Transpl. 2006, 12, 184-194. [CrossRef]

28. Turbeville, S.; Nicely, H.; Rizzo, J.D.; Pedersen, T.L.; Orchard, P.J.; Horwitz, M.E.; Horwitz, M.E.; Veys, P.; Bonfim, C.; Al-Seraihy, A. Clinical outcomes following hematopoietic stem cell transplantation for the treatment of mucopolysaccharidosis VI. Mol. Genet. Metab. 2011, 102, 111-115. [CrossRef]

29. Wang, J.; Luan, Z.; Jiang, H.; Fang, J.; Qin, M.; Lee, V.; Chen, J. Allogeneic hematopoietic stem cell transplantation in thirty-four pediatric cases of mucopolysaccharidosis- a ten year report from the China Children Transplant Group. Biol. Blood Marrow Transpl. 2016, 22, 2104-2108. [CrossRef] 
30. Yabe, H.; Tanaka, A.; Chinen, Y.; Kato, S.; Sawamoto, K.; Yasuda, E.; Shintaku, H.; Suzuki, Y.; Orii, T.; Tomatsu, S. Hematopoietic stem cell transplantation for Morquio A syndrome. Mol. Genet. Metab. 2016, 117, 84-94. [CrossRef]

31. Yamada, Y.; Kato, K.; Sukegawa, K.; Tomatsu, S.; Fukuda, S.; Emura, S.; Kojima, S.; Matsuyama, T.; Sly, W.S.; Kondo, N. Treatment of MPS VII (Sly disease) by allogeneic BMT in a female with homozygous A619V mutation. Blood Marrow Transpl. 1998, 21, 629-634. [CrossRef]

32. Tomatsu, S.; Alméciga-Díaz, C.J.; Montaño, A.M.; Yabe, H.; Tanaka, A.; Dung, V.C.; Giugliani, R.; Kubaski, F.; Mason, R.W.; Yasuda, E.; et al. Therapies for the bone in mucopolysaccharidoses. Mol. Genet. Metab. 2015, 114, 94-109. [CrossRef]

33. Tanjuakio, J.; Suzuki, Y.; Patel, P.; Yasuda, E.; Kubaski, F.; Tanaka, A.; Yabe, H.; Mason, R.W.; Montaño, A.W.; Orii, K.E.; et al. Activities of daily living in patients with Hunter syndrome: Impact of enzyme replacement therapy and hematopoietic stem cell transplantation. Mol. Genet. Metab. 2015, 114, 161-169. [CrossRef] [PubMed]

34. Aldenhoven, M.; Wynn, R.F.; Orchard, P.J.; O’Meara, A.; Veys, P.; Fischer, A.; Valayannopoulos, V.; Neven, B.; Rovelli, A.; Prasad, V.K.; et al. Long-term outcome of Hurler syndrome patients after hematopoietic cell transplantation: An international multicenter study. Blood 2015, 125, 2164-2172. [CrossRef] [PubMed]

35. Mitchell, R.; Nivison-Smith, I.; Anazodo, A.; Tiedemann, K.; Shaw, P.J.; Teague, L.; Fraser, C.J.; Carter, T.L.; Tapp, H.; Alvaro, F.; et al. Outcomes of haematopoietic stem cell transplantation for inherited metabolic disorders: A report from the Australian and New Zealand Children's Haematology Oncology Group and the Australasian Bone Marrow Transplant Recipient Registry. Pediatr. Transpl. 2013, 17, 582-588. [CrossRef] [PubMed]

36. Vellodi, A.; Young, E.; Cooper, A.; Lidchi, V.; Winchester, B.; Wraith, J.E. Long-term follow-up following bone marrow transplantation for Hunter disease. J. Inherit. Metab. Dis. 1999, 22, 638-648. [CrossRef]

37. Stoop, F.J.; Kruyt, M.C.; van der Linden, M.H.; Sakkers, R.J.B.; van Hasselt, P.M.; Castelein, R.M.C. Prevalence and development of orthopaedic symptoms in the dutch hurler patient population after haematopoietic stem cell transplantation. Jimd Rep. 2013, 9, 17-29.

38. Taylor, C.; Brady, P.; O’Meara, A.; Moore, D.; Dowling, F.; Fogarty, E. Mobility in Hurler syndrome. J. Pediatr. Orthop. 2008, 28, 163-168. [CrossRef]

39. Langereis, E.L.; Borgo, A.; Crushell, E.; Harmatz, P.R.; van Hasselt, P.M.; Jones, S.A.; Kelly, P.M.; Lampe, C.; van der Lee, J.H.; Odent, T.; et al. Treatment of hip dysplasia in patients with mucopolysaccharidosis type I after hematopoietic stem cell transplantation: Results of an international consensus procedure. Orphanet. J. Rare Dis. 2013, 3, 155. [CrossRef]

40. Masterson, E.L.; Murphy, P.G.; O’Meara, A.; Moore, D.P.; Dowling, F.E.; Fogarty, E.E. Hip dysplasia in Hurler's syndrome: Orthopaedic management after bone marrow transplantation. J. Pediatr. Orthop. 1996, 16, 731-733. [CrossRef]

41. Friso, A.; Tomanin, R.; Salvalaio, M.; Scarpa, M. Genistein reduces glycosaminoglycan levels in a mouse model of mucopolysaccharidosis type II. Br. J. Pharm. 2010, 159, 1082-1091. [CrossRef]

42. Malinowska, M.; Wilkinson, F.L.; Bennett, W.; Langford-Smith, K.J.; O'Leary, H.A.; Jakobkiewicz-Banecka, J.; Wynn, R.; Wraith, J.E.; Wergzyn, G.; Bigger, B.W. Genistein reduces lysosomal storage in peripheral tissues of mucopolysaccharide IIB mice. Mol. Genet. Metab. 2009, 98, 235-242. [CrossRef] [PubMed]

43. Parsons, C.L. The therapeutic role of sulfated polysaccharides in the urinary bladder. Urol. Clin. North. Am. 1994, 21, 93-100. [PubMed]

44. Sadhukhan, P.C.; Tchetgen, M.B.; Rackley, R.R.; Vasavada, S.P.; Liou, L.; Bandyopadhyay, S.K. Sodium pentosan polysulfate reduces urothelial responses to inflammatory stimuli via an indirect mechanism. J. Urol. 2002, 168, 289-292. [CrossRef]

45. Chiang, G.; Patra, P.; Letourneau, R.; Jeudy, S.; Boucher, W.; Green, M.; Sant, G.R.; Theoharides, T.C. Pentosanpolysulfate inhibits mast cell histamine secretion and intracellular calcium ion levels: An alternative explanation of its beneficial effect in interstitial cystitis. J. Urol. 2002, 164, 2119-2125. [CrossRef]

46. Kwan, C.; Bell, R.; Koenig, T.; Bischofberger, A.; Horadagoda, N.; Perkins, N.R.; Jeffcott, L.B.; Dart, A.J. Effects of intra-articular sodium pentosan polysulfate and glucosamine on the cytology, total protein concentration and viscosity of synovial fluid in horses. Aust. Vet. J. 2012, 90, 315-320. [CrossRef] [PubMed] 
47. Takizawa, M.; Yatabe, T.; Okada, A.; Chijiiwa, M.; Mochizuki, S.; Ghosh, P.; Okada, Y. Calcium pentosan polysulfate directly inhibits enzymatic activity of ADAMTS4 (aggrecanase-1) in osteoarthritic chondrocytes. Febs Lett. 2008, 582, 2945-2949. [CrossRef]

48. Donida, B.; Marchetti, D.P.; Biancini, G.B.; Deon, M.; Manini, P.R.; da Rosa, H.T.; Moura, D.J.; Saffi, J.; Bender, F.; Burin, M.G.; et al. Oxidative stress and inflammation in mucopolysaccharidosis type IVA patients treated with enzyme replacement therapy. Bba-Mol. Basis Dis. 2015, 1852, 1012-1019. [CrossRef]

49. Simonaro, C.M.; Ge, Y.; Eliyahu, E.; He, X.; Jepsen, K.J.; Schuchman, E.H. Involvement of the toll-like receptor 4 pathway and use of TNF- $\alpha$ antagonists for treatment of the mucopolysaccharidoses. Proc. Natl. Acad. Sci. USA 2010, 107, 222-227. [CrossRef]

50. Simonaro, C.M.; D'Angelo, M.; Xingxuan, H.; Eliyahu, E.; Shtraizent, N.; Haskins, M.E.; Schuchman, E.H. Mechanism of glycosaminoglycan-mediated bone and joint disease: Implications for the mucopolysaccharidoses and other connective tissue diseases. Am. J. Pathol. 2008, 172, 112-122. [CrossRef]

51. Simonaro, C.M.; D'Angelo, M.; Haskins, M.E.; Schuchman, E.H. Joint and bone disease in mucopolysaccharidoses VI and VII: Identification of new therapeutic targets and biomarkers using animal models. Pediatr. Res. 2005, 57, 701-707. [CrossRef]

52. Frohbergh, M.; Ge, Y.; Meng, F.; Karabul, N.; Solyom, A.; Lai, A.; Iatridis, J.; Schuchman, E.H.; Simonaro, C.M. Dose responsive effects of subcutaneous pentosan polysulfate injection in mucopolysaccharidosis Type VI rats and comparison to oral treatment. PLOS ONE 2014. [CrossRef] [PubMed]

53. Schuchman, E.H.; Ge, Y.; Lai, A.; Borisov, Y.; Faillace, M.; Eliyahu, E.; He, X.; Iatridis, J.; Vlassara, H.; Striker, G. Pentosan polysulfate: A novel therapy for mucopolysaccharidoses. PLoS ONE 2013. [CrossRef] [PubMed]

54. Simonaro, C.M.; Tomatsu, S.; Sikora, T.; Kubaski, F.; Frohbergh, M.; Guevara, J.M.; Wang, R.Y.; Vera, M.; Kang, J.L.; Smith, L.J. Pentosan polysulfate: Oral versus subcutaneous injection in mucopolysaccharidosis Type I dogs. PLoS ONE 2016. [CrossRef] [PubMed]

55. Crivaro, A.N.; Mucci, J.M.; Bondar, C.M.; Ormazabal, M.E.; Ceci, R.; Simonaro, C.; Rozenfeld, P.A. Efficacy of pentosan polysulfate in in vitro models of lysosomal storage disorders: Fabry and Gaucher Disease. PLoS ONE 2019. [CrossRef] [PubMed]

56. Guo, N.; DeAngelis, V.; Zhu, C.; Schuchman, E.H.; Simonaro, C.M. Pentosan polysulfate treatment of mucopolysaccharidosis Type IIIA mice. Jimd Rep. 2019. [CrossRef]

57. Hennermann, J.B.; Gökce, S.; Solyom, A.; Mengel, E.; Schuchman, E.H.; Simonaro, C.M. Treatment with pentosan polysulphate in patients with MPS I: Results from an open label, randomized, monocentric phase II study. J. Inherit. Metab. Dis. 2016, 39, 831-837. [CrossRef]

58. Oguma, T.; Tomatsu, S.; Montano, A.M.; Okazaki, O. Analytical method for the determination of disaccharides derived from keratan, heparan, and dermatan sulfates in human serum and plasma by high-performance liquid chromatography/turbo ionspray ionization tandem mass spectrometry. Anal. Biochem. 2007, 368, 79-86. [CrossRef] [PubMed]

59. Oguma, T.; Tomatsu, S.; Okazaki, O. Analytical method for determination of disaccharides derived from keratan sulfates in human serum and plasma by high-performance liquid chromatography/turbo-ionspray ionization tandem mass spectrometry. Biomed. Chromatogr. 2007, 21, 356-362. [CrossRef] [PubMed]

60. Tomatsu, S.; Montano, A.M.; Oguma, T.; Dung, V.C.; Oikawa, H.; Gutiérrez, M.L.; Yamaguchi, S.; Suzuki, Y.; Fukushi, M.; Barrera, L.A. Validation of disaccharide compositions derived from dermatan sulfate and heparan sulfate in mucopolysaccharidoses and mucolipidoses II and III by tandem mass spectrometry. Mol. Genet. Metab. 2010, 99, 124-131. [CrossRef]

61. Rowan, D.J.; Tomatsu, S.; Grubb, J.H.; Montaño, A.M.; Sly, W.S. Assessment of bone dysplasia by micro-CT and glycosaminoglycan levels in mouse models for mucopolysaccharidosis type I., IIIA, IVA, and VII. J. Inherit. Metab. Dis. 2013, 36, 235-246. [CrossRef]

62. Tomatsu, S.; Montaño, A.M.; Oguma, T.; Dung, V.C.; Oikawa, H.; de Carvalho, T.G.; Guitierrez, M.L.; Yamaguchi, S.; Suzuki, Y.; Fukushi, M.; et al. Validation of keratan sulfate level in mucopolysaccharidosis type IVA by liquid chromatography-tandem mass spectrometry. J. Inherit. Metab. Dis. 2010, 33, 35-42. [CrossRef] [PubMed]

63. Hintze, J.P.; Tomatsu, S.; Fujii, T.; Montaño, A.M.; Yamaguchi, S.; Suzuki, Y.; Fukushi, M.; Ishimaru, T.; Orii, T. Comparison of liquid chromatography-tandem mass spectrometry and sandwich ELISA for determination of keratan sulfate in plasma and urine. Biomark Insights 2011, 6, 69-78. [CrossRef] [PubMed] 
64. Shaukat, A.K.; Mason, R.W.; Giugliani, R.; Orii, K.; Fukao, T.; Suzuki, Y.; Yamaguchi, S.; Kobayashi, H.; Orii, T.; Tomatsu, S. Glycosaminoglycans analysis in blood and urine of patients with mucopolysaccharidosis. Mol. Genet. Metab. 2018, 125, 44-52.

65. Suzuki, Y.; Aoyama, A.; Kato, T.; Shimozawa, N.; Orii, T. Retinitis pigmentosa and mucopolysaccharidosis type II: An extremely attenuated phenotype. J. Inherit. Metab. Dis. 2009, 32, 582-583. [CrossRef] [PubMed]

66. Isogai, K.; Sukegawa, K.; Tomatsu, S.; Fukao, T.; Song, X.-Q.; Yamada, Y.; Fukuda, S.; Orii, T.; Kondo, N. Mutation analysis in the iduronate-2-sulphatase gene in 43 Japanese patients with mucopolysaccharidosis type II (Hunter disease). J. Inher. Metab. Dis. 1998, 21, 60-70. [CrossRef] [PubMed]

67. Kato, T.; Kato, Z.; Kuratsubo, I.; Tanaka, N.; Ishigami, T.; Kajihara, J.; Sukegawa-Hayasaka, K.S.; Orii, K.; Isogai, K.; Toshiyuki, F.; et al. Mutational and structural analysis of Japanese patients with mucopolysaccharidosis type II. J. Hum. Genet. 2005, 50, 395-402. [CrossRef] [PubMed]

68. Brusius-Facchin, A.C.; Schwarts, I.V.D.; Zimmer, C.; Ribeiro, M.G.; Acosta, A.X.; Horovitz, D.; Monlleó, I.L.; Fontes, M.I.B.; Fett-Conte, A.; Oliveira-Sobrinho, R.P.; et al. Mucopolysaccharidosis type II: Idenfication of 30 novel mutations among Latin American Patients. Mol. Genet. Metab. 2013, 111, 133-138. [CrossRef] [PubMed]

69. Joffe, S. Drug prevention of postoperative deep vein thrombosiss. A comparative study of calcium heparinate and sodium pentosan polysulfate. Arch. Surg. 1979, 111, 37-40. [CrossRef]

70. Opoka-Winiarska, V.; Jurecka, A.; Emeryk, A.; Tylki-Syzmanska, A. Osteoimmunology in mucopolysaccharidoses type I., II, VI and VII. Immunological regulation of the osteoarticular system in the courof metabolic inflammation. Osteoarthr. Cartil. 2013, 21, 1813-1823. [CrossRef]

71. Zhang, J.; An, J. Cytokines, inflammation and pain. Int. Anesth. Clin. 2009, 45, 27-37. [CrossRef]

72. Roberts, A.L.; Rees, M.H.; Klebe, S.; Flecher, J.M.; Byers, S. Improvement in behavior after substrate deprivation therapy with rhodamine B in a mouse model of MPS IIIA. Mol. Genet. Metab. 2007, 92, 115-121. [CrossRef] [PubMed]

73. Derrick-Roberts, A.L.K.; Jackson, M.R.; Pyragius, C.E.; Byers, S. Substrate deprivation therapy to reduce glycosaminoglycan synthesis improves aspects of neurological and skeletal pathology in MPS I mice. Diseases 2017, 5, 5. [CrossRef] [PubMed]

74. Derrick-Roberts, A.L.; Marais, W.; Byers, S. Rhodamine B and 2-acetamido-1,3,6-tri-O-acetyl-4-deoxy-4-fluoroD-glucopyranose (F-GlcNAc) inhibit chondroitin/dermatan and keratan sulphate synthesis by different mechanisms in bovine chondrocytes. Mol. Genet. Metab. 2012, 106, 214-220. [CrossRef] [PubMed]

75. Piotrowska, E.; Jakóbkiewicz-Banecka, J.; Barańska, S.; Tylki-Szymańska, A.; Czartoryska, B.; Wegrzyn, A.; Wegrzyn, G. Genistein-mediated inhibition of glycosaminoglycan synthesis as a basis for gene expression-targeted isoflavone therapy for mucopolysaccharidoses. Eur. J. Hum. Genet. 2006, 14, 846-852. [CrossRef] [PubMed]

76. Jakóbkiewicz-Banecka, J.; Piotrowska, E.; Narajczyk, M.; Barańska, S.; Wegrzyn, G. Genistein-mediated inhibition of glycosaminoglycan synthesis, which corrects storage in cells of patients suffering from mucopolysaccharidoses, acts by influencing an epidermal growth factor-dependent pathway. J. Biomed. Sci. 2009. [CrossRef]

77. Moskot, M.; Gabig-Cimińska, M.; Jakóbkiewicz-Banecka, J.; Węsierska, M.; Bocheńska, K.; Węgrzyn, G. Cell cycle is disturbed in mucopolysaccharidosis type II fibroblasts, and can be improved by genistein. Gene 2016, 585, 100-103. [CrossRef]

(C) 2019 by the authors. Licensee MDPI, Basel, Switzerland. This article is an open access article distributed under the terms and conditions of the Creative Commons Attribution (CC BY) license (http://creativecommons.org/licenses/by/4.0/). 